\title{
KICKING THE BUTT OF SECONDHAND SMOKE: WHY INDIANA SHOULD BAN SMOKING IN VEHICLES CARRYING MINORS
}

\author{
Jennifer L. Strange*
}

TABLE OF CONTENTS

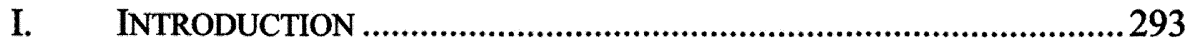

A. What is Secondhand Smoke?................................................. 294

B. Dangers of Secondhand Smoke: The Shift from "Smoking is Bad for You" to "Smoking is Bad for Others".

1. Smoking may be harmful to YOUR health-focus on the smoker (Reports of the Surgeon General from the 1960s to the mid-1980s).

2. Smoking is harmful to your health and $M A Y$ be harmful to OTHERS-focus on the gray (Reports of the Surgeon General from the mid-1980s to the late 1990s).

3. Beyond a mere annoyance: smoking IS harmful to othersfocus on the effects of SHS (Current reports of the Surgeon General)...

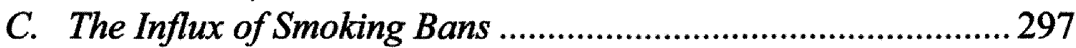

1. The birth of the "smoking ban" ..........................................297

2. The growth of the "smoking ban"..................................297

3. The change in the "smoking ban"..................................... 298

D. Giving a Voice to the Voiceless: Protecting Children..............299

1. The harmful effect of SHS on children...............................299

2. Actions by states and courts to protect children from exposure to $S H S$............................................................. 300

3. SHS exposure in vehicles: the effects on children.............. 301

II. MOVING FROM THE PUBLIC TO THE PRIVATE: THE NEED FOR REGULATING PRIVATE VEHICLES IN ORDER TO PROTECT CHILDREN.

A. Two States Take the Lead: Arkansas and Louisiana Pass

Smoking Bans on Vehicles ..................................................... 302

1. Arkansas ........................................................................ 302

2. Louisiana..................................................................... 303

B. Stretching the Ban Even Farther: A Look at Bangor, Maine and the State of California ............................................................. 303

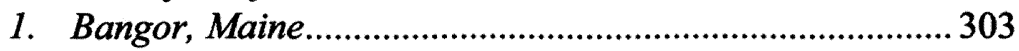

* J. D. Candidate, 2009, Indiana University School of Law-Indianapolis; B.A., 2005, Butler University. 
2. California

C. Jumping on the Bandwagon: Other States Take Note of the Problem.

D. Beyond the United States: Other Countries Propose National Smoking Bans on Vehicles Carrying Minors .......................... 306

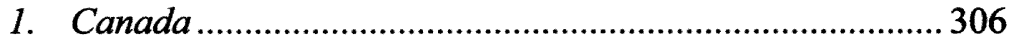

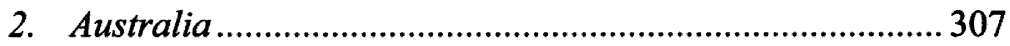

III. OKAY TO BE A NANNY: PROTECTING CHILDREN OUTWEIGHS PERSONAL RIGHTS (WHY ARGUMENTS AGAINST THIS TYPE OF BAN FAIL) 308

A. Is the Government Going Too Far by Regulating the "Private"

Vehicle?: The Rights of the Smoker vs. the Interests of the Child. 308

1. The privacy argument ..................................................... 308

2. Parens patriae: the interests of the child trump the rights of the smoker.

B. How Will the Government Enforce a Smoking Ban on Vehicles?:

The Enforceability Argument

C. Breaking Down the Walls of the "Castle"-the Government is Already Regulating the "Private" Sphere to Protect Against SHS....

1. SHS as a nuisance - the increase in smoke-free apartments, condominiums ("condos"), and other rental properties ... 313

2. Not protecting against SHS may be a violation of the covenant of quiet enjoymentand/or the implied warranty of habitability-landlord/tenant cases.

D. A Minor Restrained in a Smoky Vehicle is Like a Prisoner

Confined to a Cell-A Parallel to Smoking Bans in Prisons ... 316

IV. IT IS TIME FOR INDIANA TO TAKE ACTION: INDIANA NEEDS TO PASS

A SMOKING BAN ON VEHICLES CARRYING MINORS ...................... 319

A. Smoking \& Indiana: The Startling Statistics........................... 319

B. Common Sense Legislation: A Proposed Plan for Indiana..... 319

1. A step in the right direction: the ban that almost was ...... 319

2. Where does Indiana go from here? .................................. 321

V. CONCLUSION ........................................................................... 323

Kid: My Mommy says smoking kills.

Nick Naylor: Oh, is your Mommy a doctor?

Kid: No.

Nick Naylor: A scientific researcher of some kind?

Kid: No.

Nick Naylor: Well then she's hardly a credible expert, is she? 
Nick Naylor: My point is that you have to think for yourself. If your parents told you that chocolate was dangerous, would you take their word for it?

Children (in unison): No!

Nick Naylor: Exactly! So perhaps instead of acting like sheep when it comes to cigarettes, you should find out for yourself. ${ }^{1}$

\section{INTRODUCTION}

Smoking bans are not a new concept. The harmful effects of secondhand smoke ("SHS") have been known for many years, but it was not until 2006when it was concluded that there is no safe level of $\mathrm{SHS}^{2}$ - that the full scope of the dangers of SHS came to light. It has only been in the past few years that the particularly damaging effects of SHS on children have been fully realized. ${ }^{3}$ Despite these disturbing new findings, children remain largely unprotected by smoking bans and exposed to the dangers of SHS.

This Note closely examines the newest species of smoking bans: smoking bans in vehicles carrying minors. Part I of this Note examines the issues of SHS, smoking bans, and the effects of SHS on children. In Part II, this Note surveys the methods employed by various states and cities that have taken the lead and begun to regulate this predominantly private sphere (the vehicle). In Part III, this Note explores the arguments for and against these smoking bans, including privacy, constitutional, and enforceability arguments. In Part III, this Note ultimately suggests that states have a duty to protect children from exposure to SHS in vehicles and that the regulations are relatively easy to enforce. Part III will also examine situations in which the Government is already regulating the private sphere, such as landlord/tenant cases. Further, Part III will compare children confined in a smoky vehicle to prisoners confined in a cell and suggests that if prisoners can be spared from SHS exposure, then children should also be afforded that protection. In Part IV, this Note will argue that Indiana, a large tobacco-producing state, ${ }^{4}$ should follow the lead of Arkansas, Louisiana, and California, and pass legislation banning smoking in vehicles carrying minors. In Part V, this Note concludes that the dangers associated with SHS are too great and children are too important to not take the recommended action in regulating activities within the vehicle.

1. THANK YOU FOR SMOKING (Fox Searchlight Pictures 2005), available at http://www.foxsearchlight.com/thankyouforsmoking (scene that depicts a Big Tobacco spokesman/lobbyist talking to a classroom of children about his job as he tries to spin arguments in favor of cigarettes).

2. See infra note 28 and accompanying text.

3. See infra notes $29-30$ and accompanying text.

4. See infra note 201 and accompanying text. 


\section{A. What is Secondhand Smoke?}

SHS, or environmental tobacco smoke, is a "mixture of the smoke given off by the burning end of tobacco products (sidestream smoke) and the mainstream smoke exhaled by smokers." ${ }^{\text {"5 }}$ SHS exposure happens in both the public and private spheres. People can be exposed to SHS in private areas such as the home, vehicle, or workplace, and in public areas such as bars, restaurants, clubs, and casinos. The exposure of nonsmokers to SHS is often referred to as "passive smoking" or "involuntary smoking," rhetorically demonstrating the fact that the majority of nonsmokers are involuntarily exposed to tobacco smoke. $^{6}$

\section{B. Dangers of Secondhand Smoke: The Shift from "Smoking is Bad for You" to "Smoking is Bad for Others"}

1. Smoking may be harmful to YOUR health-focus on the smoker (Reports of the Surgeon General from the 1960s to the mid-1980s)

The dangers of smoking were first addressed in the 1964 U.S. Surgeon General's report. ${ }^{7}$ SHS was not addressed until eight years later in the 1972 Surgeon General's Report. ${ }^{8}$ In the 1972 report, the "studies supported a conclusion that 'an atmosphere contaminated with tobacco smoke can contribute to the discomfort of many individuals."'9 Further, the report contemplated the possibility of harm from SHS-it mentioned that carbon monoxide from cigarette smoke could potentially harm people with chronic heart or lung disease. ${ }^{10}$

Although the 1970s and 1980s marked a period in which it was becoming increasingly apparent that there were serious consequences from exposure to SHS, information pertaining to the dangers and effects of SHS was limited, and SHS was only briefly mentioned in reports of the Surgeon General. For example, the 1975 Surgeon General's Report stated that "smoking on buses and airplanes was annoying to nonsmokers and that involuntary smoking had potentially adverse consequences for persons with heart and lung diseases." The 1982 Surgeon General's Report noted that, "[a]lthough the currently avail-

5. U.S. Dep't of Health and Human Servs., The Health Consequences of INVOLUNTARY EXPOSURE TO TOBACCO SMOKE: A REPORT OF THE SURGEON GEN. CTR. FOR Disease Control and Prevention, CoOrdinating Ctr. For Health Promotion, Nat’l Ctr. for Chronic Disease Prevention and Health Promotion, Office on SMoKing AND Health (2006), available at http://surgeongeneral.gov/library/secondhandsmoke/report [hereinafter 2006 REPORT ] (message from Sec'y of Health and Human Servs., Michael O. Leavitt).

6. Id. at 9.

7. Id. at 3 .

8. Id.

9. Id. (emphasis added).

10. Id.

11. 2006 REPORT, supra note 5, at 3 (emphasis added). 
able evidence is not sufficient to conclude that passive or involuntary smoking causes lung cancer in nonsmokers, the evidence does raise concern about a possible serious public health problem." 12 Although these reports acknowledged a heightened concern for risks associated with SHS, the reports danced around the possibility that SHS was more than an annoyance to nonsmokers. Further, the 1984 Surgeon General's Report was the first time the effects of smoking on children were mentioned - the report only briefly reviewed the "mounting information" on parental smoking and its effects on children. ${ }^{13}$

\section{Smoking is harmful to your health and MAY be harmful to OTHERS-} focus on the gray (Reports of the Surgeon General from the mid-1980s to the late 1990s)

The 1986 Surgeon General's Report marked the first time that SHS was the focus of an entire report. ${ }^{14}$ The report concluded that "involuntary smoking caused lung cancer in lifetime nonsmoking adults and was associated with adverse effects on respiratory health in children." time, Dr. C. Everett Koop, stated that, "the right of smokers to smoke ends where their behavior affects the health and well-being of others; furthermore, it is the smoker's responsibility to ensure that they do not expose nonsmokers to the potential harmful effects of tobacco smoke." 16 These concerns were echoed by the International Agency for Research on Cancer, the World Health Organization, and the National Research Council. ${ }^{17}$

Since the 1986 Report, there has been growing information about the dangers of SHS. For example, in 1992, the U.S. Environmental Protection Agency ("EPA") classified SHS as a known human carcinogen. ${ }^{18}$ Throughout the years, research on SHS and its effects on nonsmokers has only confirmed the finding that SHS exposure is linked to numerous health problems, as originally concluded in the 1986 Surgeon General's Report. ${ }^{19}$ In 1997, the EPA estimated that exposure to SHS causes "between 24,300 and 71,900 low birth weight or pre-term deliveries, about 202,300 episodes of childhood asthma (new cases and exacerbations), between 150,000 and 300,000 cases of lower respiratory illness in children, and about 789,700 cases of middle ear infections in children" each year in the United States. ${ }^{20}$

3. Beyond a mere annoyance: smoking IS harmful to others-focus on the

12. Id. (emphasis added).

13. Id.

14. Id.

15. Id. at 6.

16. Id.

17. 2006 REPORT, supra note 5, at 6 .

18. Id.

19. Id. at 7.

20. Id. at 8 . 


\section{effects of SHS (Current reports of the Surgeon General)}

SHS continues to present a public health problem in the United States. In 2006, over 126 million nonsmokers in the United States were exposed to SHS. ${ }^{21}$ Approximately one quarter of all minor children are exposed to SHS in their homes. ${ }^{22}$ With these staggering statistics, the harmful effects of SHS have become very apparent. What makes matters worse is that people who choose not to smoke are inhaling the same chemicals and cancer-causing substances in SHS as people who do smoke. ${ }^{23}$ This is why nonsmokers can develop lung cancer and heart disease-health conditions that are typically associated with smokers-due to exposure to SHS. ${ }^{24}$ In 2005 alone, approximately 49,000 adults and 430 newborns died from diseases related to exposure from SHS. ${ }^{25}$ Further, SHS is responsible for " 150,000 [to] 300,000 new cases of bronchitis and pneumonia in children aged less than 18 months." 26 As a result, approximately 7,500 to 15,000 children are hospitalized annually. ${ }^{27}$

The truth cannot be ignored: SHS is a very real and serious health concern. As the 2006 Surgeon General's Report concluded: there is no safe level of exposure to $S H S .^{28}$ Furthermore, children are particularly vulnerable to the dangers of SHS. Not only does SHS increase the risks of sudden infant death syndrome, acute respiratory infections, ear problems, and more severe asthma in children, ${ }^{29}$ but parental smoking may exacerbate such health problems. SHS is also responsible for slowed lung growth in children. ${ }^{30}$ Establishing smokefree environments is the "most effective method" to prevent exposure to SHS. ${ }^{31}$ Merely isolating smokers and cleaning or ventilating the air is not enough; these measures, while mitigating some of the harm caused by SHS, cannot entirely eliminate SHS exposure. ${ }^{32}$

21. Dep't of Health and Human Servs., Ctrs. for Disease Control and Prevention, Smoking \& Tobacco Use: A Fact Sheet on Secondhand Smoke (2006), http://www.cdc.gov/tobacco/data statistics/fact_sheet/secondhand_smoke/ secondhandsmoke.htm [hereinafter Fact Sheet] (citing 2006 REPORT, supra note 5) (last visited Sept. 30, 2008).

22. 2006 REPORT, supra note 5 . In Kentucky, as many as $34.2 \%$ of children aged eighteen and younger are exposed to SHS in their homes. Id.

23. Vice Admiral Richard H. Carmona, U.S. Surgeon General, Remarks at the Press Conference to Launch the Health Consequences of Involuntary Exposure to Tobacco Smoke: A Report of the Surgeon General (June 27, 2006). ("Secondhand smoke has been found to contain more than 50 carcinogens and at least 250 chemicals that are known to be toxic or carcinogenic.") (remarks available at http://www.surgeongeneral.gov/news/speeches/06272006a.html).

24. Id.

25. 2006 REPORT, supra note 5 . In 2005 , an estimated 3,000 adult nonsmokers died from lung cancer, 46,000 adult nonsmokers died from coronary heart disease, and 430 newborns died from sudden infant death syndrome-all attributable to SHS exposure. Id.

26. Fact Sheet, supra note 21.

27. $I d$.

28. 2006 REPORT, supra note 5, at 11.

29. 2006 REPORT, supra note 5.

30. Id. at 11 .

31. Id.

32. Id. 


\section{The Influx of Smoking Bans}

\section{The birth of the "smoking ban"}

As more information about the dangers of SHS has emerged, the "attitude of the public toward and the social norms around secondhand smoke exposure have changed dramatically to reflect a growing viewpoint that the involuntary exposure of nonsmokers to secondhand smoke is unacceptable."33 As a result, both state and local governments have attempted to curb smoking in public places in an effort to control SHS and protect the public from harm. For example, California attempted to pass a statewide clean indoor air law via the California Clean Air Act of 1978-the first of its kind by any state. ${ }^{34}$ That proposition ultimately failed; however, twenty years later, California successfully banned smoking in bars and restaurants, ${ }^{35}$ paving the way for other states and municipalities to regulate smoking in public places.

\section{The growth of the "smoking ban"}

As a result of the change in attitudes towards SHS, the public has acknowledged a need for smoking bans: restrictions on smoking are now widely embraced by the public due to increased intolerance for involuntary exposure to SHS. ${ }^{36}$ Since California's initial attempt at passing a smoking ban, the United States has seen an increase of similar bans across the country on local, state, and federal levels. In 1988, Congress prohibited smoking on all domestic flights. ${ }^{37}$ By executive order, smoking was banned in all federal buildings in $1997 .^{38}$

Cities and states across the United States have enacted smoking bans in indoor public places, such as work buildings, restaurants, clubs, and casinos. ${ }^{39}$

33. Id. at 667 (emphasis added).

34. Mark J. Horvick, Examining the Underlying Purposes of Municipal and Statewide Smoking Bans, IND. L.J. 923, 923 (2005) (citing Stanton A. Glantz et al., The Cigarette Papers 391 (1996)).

35. Id.; see CAL. LAB. CODE $\S 6404.5$ (West 2007).

36. 2006 REPORT, supra note 5 , at 668.

37. Joni Ogle, Why Smoking Bans are a Butt to Texas: The Impact of Smoking Bans on Private Property Rights and Individual Freedom, TEX. TECH L. REV. 345, 352 (2007) (citing Jacob Sullum, For Your Own Good 16 (1998)); for smoking rules of the Federal Aviation Administration, see 14 C.F.R. $\S \S 121.317$ (c), 121.571 (a)(1)(i), 129.29, 135.117(a)(1), 135.127(a), and 252.3.

38. Id. (citing Jacob Sullum, For Your Own Good 16 (1998)); Exec. Order No. 13058, 62 Fed. Reg. 43451 (1997).

39. 2006 REPORT, supra note 5, at 668 . For example, on March 27, 2003, the city of Bloomington, Indiana passed a city-wide ordinance banning smoking. Monroe County, Ind., Ordinance 03-06: "Smoking in Public Places and Places of Employment" (March 27, 2003), available at $\mathrm{http}: / / \mathrm{www} . s m o k e f r e e b l o o m i n g t o n . o r g / o r d 0306$ final.pdf. As of January 1, 2005, all public places (including bars and restaurants) and places of employment were smoke-free. Id. 
Many colleges, universities, nursing homes, and hospitals have joined the smoke-free movement and have enacted policies that prohibit smoking on campuses. ${ }^{40}$ The United States military has even adopted smoking restrictions within their indoor facilities. ${ }^{41}$ By prohibiting smoking in public places, several levels of government have recognized and reinforced the Surgeon General's conclusion that merely separating smokers from nonsmokers in public places does not effectively eliminate the health risks associated with SHS ${ }^{42}$ In 2007 , seven states passed legislation that reinforced and expanded existing smokefree policies. ${ }^{43}$ To date, twenty-two states, the District of Columbia, and Puerto Rico have approved comprehensive smoke-free policies that prohibit smoking in restaurants and bars. ${ }^{44}$ Even Tennessee, the "first traditional tobacco growing state," passed smoking restrictions in 2007 in public places and workplaces. ${ }^{45}$

\section{The change in the "smoking ban"}

In response to the 2006 Surgeon General's Report, there has been a recent push for expanding smoking bans to public places that have not been covered by traditional bans. For example, the Chicago Park District recently passed a smoking ban for parks, playgrounds, and beaches. ${ }^{46}$ Violators of the ordinance

40. For example, Indiana University required all of its university property across the state of Indiana to adopt smoke-free policies for their campuses to go into effect by January 1, 2008. Indiana University, Tobacco-Free IU(Nov. 6, 2007), http://smokefree.indiana.edu/ (last visited Sept. 30,2008$)$. The university stated that "[a]s a public institution of higher education with units that research and treat the effects of smoking and tobacco use, IU believes it has an obligation to exercise leadership by promoting a healthy, smoke-free environment for its students, employees, and visitors." Id. Further, as of 2006, there were two nursing homes and sixty-five state hospitals and clinics across the state of Indiana that had adopted $100 \%$ smoke-free policies on their campuses. American Nonsmokers' Rights Foundation, 100\% Smokefree U.S. Hospitals and Nursing Homes (April 17, 2006), http://www.kidslivesmokefree.org/pdf/smokefreehealthcar e.pdf (last visited Sept. 30, 2008). These smoke-free nursing homes, hospitals, and clinics prohibit smoking in facility buildings, outdoor areas, and parking lots in order to protect employees, visitors, and patients from the harmful effects of SHS. Id.

41. Scott C. Wilcox, Secondhand Smoke Signals From Prison, 105 Mich. L. Rev. 2081, 2092 (2007) (citing 2006 REPORT, supra note 5).

42. 2006 REPORT, supra note 5.

43. AMERICAN LUNG ASSOCIATION, 2007 STATE LEGISLATED ACTIONS ON TOBACCO ISSUES MID-TERM REPORT (July 2007), available at http://slati.lungusa.org/reports/SLATI2007Mid TermReport.pdf. These states are: Illinois, Maryland, Minnesota, New Hampshire, New Mexico, Oregon, and Tennessee. Id.

44. Id. These states are: Arizona, California, Colorado, Connecticut, Delaware, Hawaii, Illinois, Maine, Maryland, Massachusetts, Minnesota, Montana, New Hampshire, New Jersey, New Mexico, New York, Ohio, Oregon, Rhode Island, Utah, Vermont, and Washington. Id. Laws in three of the states (Oregon, Utah, and Montana) go into effect in 2009. Id.

45. Id.

46. CBS2, New Smoking Ban Passes in Chicago: No Lighting Up at Beaches, Parks, Playgrounds (Oct. 17, 2007), http://cbs2chicago.com/local/smoking.ban.beaches.2.377241.html (last visited Sept. 30, 2008). 
will be forced to pay a $\$ 500$ fine. ${ }^{47}$ Chicago Park District Superintendent, Tim Mitchell, stated "I have a lot of sympathy for smokers, but not when secondhand smoke affects the health of other people."48 Although Chicago's ban protects the health of residents both young and old from SHS, it is worth noting that its protective force applies largely to children, the typical patrons of parks, playgrounds, and beaches.

England and other parts of the United Kingdom have also jumped on the non-traditional bandwagon. England recently passed a smoking ban on company vehicles. Effective July 1, 2007, smoking in company vehicles in England is prohibited if the vehicle transports more than one person. ${ }^{49}$ Wales and Northern Ireland passed a similar ban; Scotland has a more relaxed ban that applies only to vans. ${ }^{50}$ Although no state or municipality has passed such a ban in the United States, it is foreseeable that company vehicles could soon be regulated in the United States as well.

\section{Giving a Voice to the Voiceless: Protecting Children}

\section{The harmful effect of SHS on children}

Although in recent years the dangers of SHS have come to light and states and municipalities have responded with increased smoking bans, children remain an "exposed population." While smoking bans in public places (i.e. bars and restaurants) address a legitimate public health concern, they do not adequately address the effects of SHS exposure on children because children are not typically patrons in the types of public places regulated by the current smoking bans. As a result, "reductions in exposure [to secondhand smoke] have been slower among young children than among adults during the last decade." 52

SHS is particularly dangerous to children because their bodies are still developing. It has been suggested that SHS may be even more harmful to children than adults because children have weaker immune systems. "[D]ue to [children's] smaller airways and greater demand for oxygen, they may be more vulnerable to respiratory diseases." ${ }^{2}$ Exposure to SHS "increases the risk of

47. Id.

48. Id.

49. Pinsent Masons, SMoking BAN - COMPANy Vehicles (ENGLAND ANd APPlication IN OTHER PARTS OF THE UK) (June 2007), available at http://www.pinsentmasons.com/media/ 134379445.pdf.

50. Id.

51. 2006 REPORT, supra note 5, at 668 .

52. 2006 REPORT, supra note 5 , at 667 .

53. Press Release, Harvard School of Public Health, Secondhand Smoke in Cars May Lead to Dangerous Levels of Contaminants For Children (Oct. 5, 2006) [hereinafter Harvard Study], http://www.hsph.harvard.edu/news/press-releases/2006-releases/press10052006.html (last visited Sept. 30, 2008)

54. Id. 
serious respiratory problems in children, such as greater number and severity of asthma attacks and lower respiratory tract infections, and increases the risk for middle ear infections." 55 While most adults are able to decide for themselves whether to be around SHS in an environment that is not regulated by smoking bans, children are not permitted that luxury. In effect, children are unable to voice their concerns about SHS and are unable to protect themselves.

\section{Actions by states and courts to protect children from exposure to SHS}

Recognizing that children are especially vulnerable to SHS exposure, states and even the courts have taken measures to protect children from exposure. Several states have passed legislation that prohibits smoking around children in child care or foster care settings. ${ }^{56}$ The Texas Administration Code states that "[p]eople must not smoke or use tobacco products at the child-care center, on the premises, on the playground, in transportation vehicles, or during field trips [of, or sponsored by, these facilities]."57 The Washington Revised Code states that smoking is prohibited "in the living space of any home or facility caring for [foster] children and in motor vehicles while transporting [foster] children ... [Foster parents] may permit adults to smoke outdoors away from children." ${ }^{\text {.58 }}$ The Indiana Code states that smoking is also prohibited "in a school bus during a school week or while the school bus is being used for . . . [school services]" such as transporting school children to and from school, school athletic games or contests, or other school functions. ${ }^{59}$

Some courts have addressed SHS in child custody decisions. In the case of In re Julie Anne, ${ }^{60}$ a minor child was exposed to SHS by adults who smoked around the child, in public as well as in their home. ${ }^{61}$ The Ohio court, in custody and visitation proceedings pertaining to the child (who was in good health), ordered the parents to not smoke around the child. ${ }^{62}$ The court further ordered the parents to not allow others to smoke around the child. ${ }^{63}$ In issuing its order, the court acknowledged that SHS is a very real threat to the health of children and should be given consideration in determining custody of the child. ${ }^{64}$ Fur-

55. 2006 REPORT, supra note 5.

56. Pam Belluck, Maine City Bans Smoking in Cars Carrying Children, N.Y. TIMES, Jan. 19, 2007, available at http:/query.nytimes.com/gst/fullpage.html?sec=health\&res=9D04E3D C1E30F93AA25752C0A9619C8B63 (last visited Sept. 30, 2008). "At least seven states, including several with large numbers of smokers like Texas, Oklahoma and Alaska, prohibit or sharply restrict smoking around foster children in homes, cars or both. Some [states] require homes or cars to be smoke-free for 12 hours before a foster child enters." Id.

57. 40 TEX. ADMIN. CODE $\S 746.3703$ (d) (2008).

58. WASH. ADMIN. CODE 388-148-0185 (2008).

59. IND. CODE \& 16-41-37-4 (2008).

60. 780 N.E.2d 635 (Ohio Misc. 2d 2002).

61. Id. at 640 .

62. Id.

63. Id.

64. Id. 
ther, the court stated that "[a] considered analysis of the law . . . leads to the inescapable conclusions that a family court that fails to issue court orders restraining persons from smoking in the presence of children within its care is failing the children whom the law has entrusted to its care." 65

In DeMatteo v. DeMatteo, a case in New York, a minor child complained about his mother smoking in his presence during visitations. ${ }^{66}$ The court held that the interests of the child were best served if he was not exposed to SHS by his parents. ${ }^{67}$ The court further held that the mother could not smoke in her home before visits with her child, and that both the mother and father could not smoke in their vehicles if the child was present. ${ }^{68}$ In its decision, the court noted that "there is 'a substantial body of research showing that breathing second-hand smoke is a significant health hazard for non-smokers." presents a very real health concern, as evidenced by these courts and others' willingness to factor in SHS into a child custody and/or visitation decision. ${ }^{70}$

\section{SHS exposure in vehicles: the effects on children}

In spite of the attempts by states and courts to shield children from the dangers of SHS, children are still exposed to SHS in their homes and in vehicles. Because this Note is in favor of smoking bans on vehicles carrying minors, this section of the Note focuses specifically on SHS exposure in vehicles and its damaging effects on children. In the "first study to measure SHS in cars in real driving conditions," researchers from the Harvard School of Public Health concluded that "SHS in cars poses a potentially serious threat to children's health."71

Approximately $35 \%$ to $45 \%$ of children are regularly exposed to SHS in their homes and in cars. ${ }^{72}$ "[S]moking in cars can produce unsafe levels of SHS. Even with the driver's window slightly open, ... concentrations [of

65. Id. at 641. (emphasis added).

66. Dematteo v. Dematteo, 749 N.Y.S2d 671 (N.Y. Sup. Ct. 2002)

67. Id. at 679 .

68. Id.

69. Id. at 648 .

70. See Heagy v. Kean, 864 N.E.2d 383 (Ind. Ct. App. 2007) (court ordered the mother to refrain from smoking in the child's presence and after alleged violations of the order, the father requested a modification of the custody arrangements); Unger v. Unger, 274 N.J. Super. 532 (1994) (noting that parental smoking can be factored into a custody determination); Johnita, M.D. v. David, D.D., 740 N.Y.S.2d 811 (N.Y. App. Div. 2002) (court took judicial notice of exposure to SHS after a thirteen-year-old asked the court that he not be exposed to SHS during visits with his mother); Becker v. Becker, 925 P.2d 162 (Or. Ct. App. 1996) (judgment of dissolution contained a provision prohibiting both parents and third parties from smoking cigarettes around the children).

71. Harvard Study, supra note 53. The study consisted of forty-five driving trials, which averaged about an hour each. Id. During the trials, volunteers smoked cigarettes while driving. Id. Throughout the study, "measurement devices were positioned in an empty child restrainer seat at simulated head level" that detected and measured SHS levels. Id.

72. Id. 
SHS] hit levels rated 'hazardous' by the ... [EPA]." "73 Even "smoking a single cigarette for just five minutes could produce potentially harmful . . . levels [of SHS]." "The smoke particle levels ... measured are alarming and are above the threshold for what's considered unhealthy for sensitive groups-people like children and the elderly ... Adults who smoke while driving their children may be harming them more than they realize."75 It has been found that SHS exposure for mere seconds is still incredibly dangerous and can cause children to have asthma attacks. ${ }^{76}$ To make things worse, children are often physically restrained in smoky cars, with SHS levels similar to that of smoke-filled bars or restaurants. ${ }^{77}$ The Harvard School of Public Health study, when considered alongside the 2006 Surgeon General's Report, confirms the fact that states need to speak and act on behalf of children to protect them from SHS in vehicles.

\section{MOVING FROM THE PUBLIC TO THE PRIVATE: THE NEED FOR REGULATING PRIVATE VEHICLES IN ORDER TO PROTECT CHILDREN}

\section{A. Two States Take the Lead ${ }^{78}$ : Arkansas and Louisiana Pass Smoking Bans on Vehicles}

\section{Arkansas}

Arkansas was the first state to pass legislation aimed at protecting children from SHS exposure in vehicles. ${ }^{79}$ In April 2006, then-governor of Arkansas, Mike Huckabee, signed into law House Bill 1046, which prohibits smoking in a vehicle carrying a child less than six years old or weighing less than sixty pounds. ${ }^{80}$ The bill, which was sponsored by Rep. Bob Mathis (D-AR), a former smoker, received "overwhelming support" and passed in less than two

73. Id.

74. Id.

75. Id.

76. Id.

77. Harvard Study, supra note 53.

78. The territory of Puerto Rico has also joined the "growing national and international trend" to enact legislation prohibiting smoking in vehicles. Tobacco Public Policy Center, $A r$ kansas Prohibits Smoking in Cars Carrying Young Children (April 2006), http://www.law.capital.edu/Tobacco/Newsletter/april2006/Feature2.asp (last visited Sept. 30, 2008). Puerto Rico's law, which took effect in March 2007, prohibits smoking in vehicles with children under the age of thirteen present. Id.

79. Rep. Peter Daley (D-Penn.) was "the first [legislator] in the nation to propose a ban on smoking in vehicles carrying children-in 1988, after he had a cancer removed from his throat that he blamed on whiffs from his mother's cigarettes." Andrew Knapp, States go After Smoking in Vehicles with Kids, Stateline (March 6, 2007), http://www.stateline.org/live/details/ story?contentId=186298 (last visited Sept. 30, 2008). The effort, however, was successfully opposed by the American Civil Liberties Union of Pennsylvania. Id. (2008).

80. Tobacco Public Policy Center, supra note 78; see also ARK. CODE ANN. § 20-27-1903 
days. ${ }^{81}$ Violators face fines of up to twenty-five dollars, but the fine for a first offense can be waived if a violator proves that he has taken measures to stop smoking. ${ }^{82}$ Governor Huckabee has acknowledged that this bill clearly protects children from the dangers of SHS. ${ }^{83}$

\section{Louisiana}

Louisiana was the second state to ban smoking in vehicles carrying children. Similar to the law in Arkansas, Louisiana's law is targeted at protecting children restrained in car seats. According to the statute, it is unlawful for the operator or any passenger in a motor vehicle to smoke cigarettes, pipes, or cigars in a motor vehicle when a child who is required to be restrained in a child safety seat is also present in such vehicle, regardless of whether the windows of the motor vehicle are down; violators face a fine of up to $\$ 150$ per offense. ${ }^{84}$ Violation of the law is considered a primary offense; therefore, police officers may stop but not search a vehicle if a violation is occurring. ${ }^{85}$

Louisiana, although following Arkansas's lead in passing legislation, took a stricter approach to fines for violators of the ban. By imposing stricter fines and penalties, Louisiana gets the message across that they do not tolerate exposing children to SHS.

\section{B. Stretching the Ban Even Farther: A Look at Bangor, Maine and the State of California}

\section{Bangor, Maine}

In January 2007, Bangor, Maine became the first city in the United States to ban smoking in vehicles carrying children. ${ }^{86}$ Bangor's ordinance extended the ban beyond children in car seats to include vehicles travelling with anyone under the age of eighteen. ${ }^{87}$ A proponent of the ordinance, council member Patricia Blanchette, stated,

81. Id.; Knapp, supra note 79.

82. ARK. CODE ANN. $§ 20-27-1904$ (2008).

83. Tobacco Public Policy Center, supra note 78.

84. See LA. ReV. StAT. ANN. § 32:300.4 (2006).

85. LA. ReV. Stat. ANN. § 32:300.3 (2006).

86. Meg Haskell, Council Supports Smoking Ban in Cars, BANGOR DAILY NEWS, Jan. 9 , 2007, at A1. Other municipalities, including Keyport, New Jersey, West Long Branch Borough, New Jersey, and Rockland County, New York have since enacted laws (of varying degrees) prohibiting smoking in vehicles carrying children. Rob Cunninham \& Michael DeRosenroll, Laws Banning Smoking in Vehicles Carrying Children-International Overview, Canadian Cancer Society (Aug. 19, 2008), http://member.globalink.org/files/file-141676-1.pdf (last visited Sept. 30, 2008).

87. Knapp, supra note 79. 
I am tired as a taxpayer of paying for people to take their children to the emergency room because they've had an asthma attack. Why are we taking these very, very fragile little bodies [of children], putting them in a confined area and allowing people to blow smoke into their lungs ${ }^{88}$

Blanchette, a smoker herself, further stated that, "[p]eople who smoke with a child present in the confined space of a car or truck might as well be deliberately trying to kill that child. Let's step up to the plate and lead; our children are worth the fight." ${ }^{, 89}$ Under the Bangor law, violating the ordinance is a primary offense, thus, police officers can make a traffic stop if they observe a violation, and violators are then subject to a $\$ 50$ fine. ${ }^{90}$ As of October 2007 , no citations had been issued in Bangor. ${ }^{91}$

\section{California}

The state of California also recently passed a smoking ban that prohibits smoking in vehicles with minors, making it the third state to pass such legislation. $^{92}$ The bill went into effect in California on January $1,2008 .^{93}$ The law makes it a secondary offense to smoke in a vehicle with children present, which means that a person would have to be stopped for some other offense- like speeding or reckless driving — in order to be penalized for smoking. ${ }^{94}$ Drivers face fines of up to $\$ 100$ for violating the law. ${ }^{95}$

\section{Jumping on the Bandwagon: Other States Take Note of the Problem}

Since Arkansas first passed its legislation banning smoking in vehicles with children present, at least sixteen other states have considered similar bans. ${ }^{96}$ Some of the proposals for smoking bans have drawn the line at children

88. Belluck, supra note 56 .

89. Haskell, supra note 86.

90. Knapp, supra note 79.

91. New England in Brief, Boston GLOBE, Oct. 22, 2007, at 2B.

92. 5AM Morning News (Fox 2 KTVU-CA broadcast Oct. 11, 2006). Since the writing of this Note, Maine became the fourth state to pass legislation regulating the vehicle. Although it did not enact a law as restrictive as the ordinance passed in its pioneer city of Bangor, Maine, the State's new law prohibits smoking in vehicles when a child under the age of sixteen is present. Me. Rev. Stat. Ann. tit. 22, $\S 1549$ (2008). Because the law is relatively new, violators will receive a written warning until August 31,2009. Id. As of September 1,2009, violators can be assessed a $\$ 50$ fine. Id.

93. 5AM Morning News (Fox 2 KTVU-CA broadcast Oct. 11, 2006).

94. Id.

95. Id.

96. Janine DeFao, Proposed Car-Smoking Ban Angers Foes of 'Nanny' Laws, SAN FRANCISCO CHRONICLE, March 26, 2007, at A-1, available at http://sfgate.com/cgibin/article.cgi?f=/ c/a/2007/03/26/MNGOLORI821.DTL. 
restrained in car seats (similar to the bans in Arkansas and Louisiana), while other states have proposed more extensive bans to include vehicles carrying children up to the age of eighteen (similar to Bangor, Maine and the state of California). ${ }^{97}$ Not only have proposals for such bans differed on the age/weight of protected children, but penalties for violating proposed bans have also varied. According to proposed legislation in Kansas, violators in the state would be warned for the first offense, while offenders under New Jersey and New York legislation could be fined $\$ 500 .^{98}$ The proposed legislation in New York allows penalties for third-time offenders (in the same year) that include up to a $\$ 1,500$ fine or ten days in jail. ${ }^{99}$

Considering that Arkansas and Louisiana have successfully enacted their bans, it is possible - and reasonable - for other states to follow suit and enact smoking bans in vehicles carrying children. Senator Scott McCoy (D-UT), who is considering a ban in Utah similar to Arkansas's ban, stated that "[w]hen we talk about children, they're some of the most vulnerable people that can be exposed to secondhand smoke. Now that I know another state has done it, it's also obvious that it is practicable or it can be done. There's certainly a precedent for it."100 Senator Raymond Lesniak (D-NJ), who sponsored a proposed ban in New Jersey, stated that "[t]here is no more important law enforcement responsibility than protecting children." 101 Senator David Haley (DKS), who amended a proposed statewide smoking ban to include vehicles carrying minors, stated that, "the act of smoking in a car with young children [is] tantamount to child abuse." 102 Senator Haley went on to state that children are "innocent victims" in these situations, and that it is time to hold adults accountable for their actions that are adversely affecting children. ${ }^{103}$

Even children, when asked, see that banning smoking in vehicles carrying children is a matter of common sense. For example, in Connecticut, Justin Kvadas, at nine-years-old, emailed his state representative (with help from his mom) and suggested that the State ban smoking in vehicles carrying children. ${ }^{104}$ Justin stated, "[i]t came to me, if you can't drink or talk on the cellphone while driving, how come you can still smoke? ... [i]t's . . bad for [children's] lungs

97. Knapp, supra note 79.

98. Id.

99. Id.

100. Brock Vergakis, Ban Smoking in Cars with Kids?, CASPER STAR TrIBUNe, April 22, 2006, available at http://www.casperstartribune.net/articles/2006/04/22/news/regional/ $9 \mathrm{ff} 28$ 2f05db18848725715700558e2b.txt.

101. Ronald Smothers, New Jersey Senate Panel Supports Penalty for Smoking in Cars with Children Aboard, NEw YORK TIMES, June 8, 2007, at B4, available at http://www.nytimes. com/ 2007/06/08/nyregion/08smoke.html.

102. Anna Staatz, Statewide Smoking Prohibition Would Include Cars with Kids, THE TOPEKA CAPITAL-JOURNAL, Jan. 25, 2007, available at $\mathrm{http}: / / \mathrm{www} . c j o n l i n e . c o m / s t o r i e s / 012507 /$ sta 141395600 .shtml.

103. Id.

104. Belluck, supra note 56. 
because their lungs are so small."105 Before presenting the proposal to his state representative, Justin circulated a petition, collecting signatures from his classmates and the mayor. ${ }^{106}$

\section{Beyond the United States: Other Countries Propose National Smoking Bans on Vehicles Carrying Minors}

\section{Canada}

In 2007, at the annual meeting of the Canadian Medical Association ("CMA"), doctors recommended a national smoking ban on vehicles carrying minors to protect children and their young lungs from harm. ${ }^{107}$ Dr. Atul Kapur recommended the ban, which received great support from the CMA. ${ }^{108}$ In his recommendation, Dr. Kapur noted the danger of SHS to children in vehicles:

The risk of second-hand smoke is quite clear to everyone in this room. There are few areas where children are still exposed [to SHS, but] one of them is vehicles. They [children] don't have a choice about whether to be exposed or not and because of the concentrated atmosphere and the enclosed space, the risk is much higher. ${ }^{109}$

A pediatrician at the meeting, Sandra Luscombe, declared that "[ $t]$ his is a child protection issue." mended law "would be no more difficult to enforce than ones requiring seatbelt usage and prohibiting drivers from talking on cellular phones."111

Although Canada has not yet passed a national smoking ban on vehicles carrying minors, it appears that the majority of the country favors such legislation. In late 2007, two provinces, Ontario and British Columbia, introduced smoking bans aimed at protecting children from SHS exposure in vehicles. ${ }^{112}$ Furthermore, in December 2007, Nova Scotia became the first province to actually enact a smoking ban on vehicles carrying minors. ${ }^{113}$ Nova Scotia's law

105. Id.

106. Id.

107. Janet Steffenhagen, Ban Smoking in Cars with Kids: Doctors, THE VANCOUVER SUN, Aug. 23, 2007, available at $\mathrm{http}: / / \mathrm{www} . c a n a d a . c o m / v a n c o u v e r s u n / s t o r y . h t m l ? i d=5 \mathrm{~d} 11855 \mathrm{c}$ 7641-4085-b1 c-ad4686022def\&k=36414\&p=1.

108. Id.

109. Id.

110. Id.

111. Id.

112. Rob Peters, Canadians Want Smoking Bans in Cars with Kids: Poll, Now Public(Jan. 17, 2008), http://www.nowpublic.com/life/canadians-want-smoking-ban-cars-kids-poll (last visited Sept. 30, 2008).

113. Id. 
defines a "minor" as anyone under the age of nineteen. ${ }^{114}$ In addition to the actions of these provinces, a national poll taken by the Canadian Cancer Society ("CCS") in January 2008 , indicated that $82 \%$ of Canadians - including $69 \%$ of Candian smokers - support the movement towards eliminating SHS exposure in vehicles when children are present. ${ }^{115}$ It is clear that the majority of Canadians think it is necessary to regulate smoking in vehicles in order to protect children. $^{116}$

\section{Australia}

The Australian Medical Association ("AMA") has also recommended that Australia prohibit smoking in vehicles carrying minors. ${ }^{117}$ In 2006 , a poll indicated that almost $90 \%$ of Australians supported such a ban. ${ }^{118}$ Furthermore, several states in Australia have introduced smoking bans on vehicles carrying minors. ${ }^{119}$ On May 31, 2007, South Australia became the first state in the country to pass a ban prohibiting smoking in vehicles when children under the age of sixteen are present. ${ }^{120}$ Violators of the South Australian law are subject to $\$ 75$ on-the-spot fines and can be forced to pay up to $\$ 200$ for violating the law. ${ }^{121}$ South Australia advertised its new legislation with posters that read, "[s]moke with kids in the car and you'll cough up a fine." 122 In announcing the enactment of the state law, South Australia's Mental Health and Substance Abuse Minister, Gail Gago, said that "[c]hildren can spend many hours in cars each week and often do not have a choice when it comes to traveling with smokers." it comes to their child's health but the few that smoke with children in the car are placing their child at considerable risk from passive smoking."

Other Australian states have also acknowledged the impact of SHS on children and have taken steps toward enacting similar legislation. For example, Victoria, a state that is generally one of the toughest on SHS exposure, has been encouraged by the AMA to follow the lead of South Australia and pass legisla-

114. Id.

115. Id.

116. See id. According to Rob Cunningham, senior policy analyst for CCS, "[t]hese poll results clearly tell us that Canadians are ready for action to protect the health of children." Id.

117. Tobacco Public Policy Center, supra note 78.

118. Id.

119. Id.

120. Media Release from S. Austl.'s Minister for Mental Health and Substance Abuse, Hon. Gail Gago, News: New Smoke-free Cars Law Begins Today (May 31, 2007) [hereinafter S. Austl. Media Release] available at $\mathrm{http} / / / \mathrm{www}$.premier.sa.gov.au/ news.php?id=1671.

121. Id.

122. Gov't of S. Austl., Dep't of Health, Smoke-Free Cars, http://www.tobaccolaws.sa. gov.au/ Default.aspx?tabid=163 (last visited Sept. 30, 2008).

123. S. Austl. Media Release, supra note 120.

124. Tobacco Public Policy Center, supra note 78. 
tion banning smoking in vehicles when children are present. ${ }^{125}$ AMA Victoria President, Dr. Mark Yates, stated that " $[\mathrm{w}]$ hile people are far more aware of the harm caused by smoking, there are still far too many people exposing children to cigarette smoke."126 Furthermore, AMA West Australia President, Paul Skerritt, referring to children as the "forgotten victims within the passive smoking debate," has strongly encouraged legislation that bans parents from smoking while driving with their children. ${ }^{127} \mathrm{Mr}$. Skerritt has poignantly compared a child restrained in a vehicle filled with SHS to someone "being locked up in a mobile gas chamber."128

\section{OKAY TO BE A NANNY: PROTECTING ChILDREN OUTWEIGHS PERSONAL RIGHTS (WHY ARGUMENTS AGAINST THIS TYPE OF BAN FAIL)}

\section{A. Is the Government Going Too Far by Regulating the "Private" Ve- hicle?: The Rights of the Smoker vs. the Interests of the Child}

\section{The privacy argument}

Considering that there is no safe level of exposure to SHS and children are more susceptible to the dangers of SHS, ${ }^{129}$ it seems reasonable to enact smoking bans on vehicles carrying minors. This is especially true because vehicles are a confined space. Critics of this particular type of smoking ban (and smoking bans in general), however, argue that this is the ultimate form of "nanny government" or "legal paternalism." "130 Because smoking bans on vehicles carrying minors reach into a traditionally private sphere, some worry that the Government is blurring the line between the types of behaviors that can and cannot be regulated (or should and should not be regulated). In response to smoking bans in vehicles, the legislative director for the American Civil Liberties Union of Pennsylvania asked, "[w] wen are we going to stop and draw the line? At some level, the people have to be responsible for what they do. We shouldn't use the law to enforce what we think is better behavior."131 It has also been argued that by passing this type of smoking ban, states are trying to

125. Press release from the AMA Victoria, Doctors Support Smoking Ban in Cars Carrying Children (Dec. 14, 2006), http://www.amavic.com.au/page/Media/WhatsNew/Doctorssupport smokingbanincarscarryingchildren (last visited Sept. 30, 2008).

126. Id.

127. Action on Smoking and Health, Australian Medical Association Pushes for Smoking Ban in Cars Carrying Children (March 16, 2005), http://no-smoking.org/march05/03-29-051.html (last visited Sept. 30, 2008).

128. Id.

129. 2006 REPORT, supra note 5 , at 11.

130. Ogle, supra note 37 , at 347 . "Legal paternalism occurs when the Government attempts to shield citizens from their own choices rather than to protect citizens' freedom of choice." Id. at 352 (citing Douglas J. Den Uyl, Smoking, Human Rights, and Civil Liberties, in Smoking: Who Has the Right? 267, 271 (1998)).

131. Knapp, supra note 79. 
regulate in an arena that is better left to parents. ${ }^{132}$ Robert Best of Smoker's Club Inc., a smokers' rights group, asked, "[w] ho is the state to tell you how you can and cannot raise your children?"133 Mr. Best further stated, "[t]here's a fine line between protecting my child and moving in to raise my child. A car is private property ... What will they do next, say you can't smoke in your home if you have kids in it?"134

Opponents of smoking bans in vehicles are predominantly concerned with privacy - people do not want the Government telling them what to do in their "private" lives. Justice Brandeis once referred to the right of privacy as the right "to be let alone - the most comprehensive of rights and the right most valued by civilized men." plainly harmful conduct, every American is left to shape his own life as he thinks best, do what he pleases, go where he pleases."136 Echoing the thoughts of Justice Brandeis and driving the arguments against smoking bans on vehicles is the premise that we, as citizens of the United States, should be free from Government intrusion into our personal lives. An extension of this premise is the common belief that a person's home is their "castle" and within their "castle," a person can do whatever he wants. Presumably, a private vehicle is part of the "castle."

While the Supreme Court has repeatedly recognized the value of personal decisions and the right to privacy, ${ }^{137}$ the right to privacy is not absolute. ${ }^{138} \mathrm{Con}$ sequently, merely because an action occurs within the "private" sphere (i.e. the vehicle), it does not necessarily follow that the action will be shielded from Government interference. Instead, this protection depends on the determination that a fundamental right is implicated. In Palko v. Connecticut, ${ }^{139}$ the Court defined a fundamental right as an interest that is "implicit in ordered liberty"140 such that "neither liberty nor justice would exist if . . . [it was] sacrificed."141 Elaborating on this definition, the Court in Griswold v. Connecticut stated that it is necessary to look to the "traditions and conscience of [the] people" to determine that a privacy interest is a fundamental right. ${ }^{142}$

132. DeFao, supra note 96.

133. Id.

134. Id.

135. Olmstead v. United States, 277 U.S. 438, 478 (1928).

136. Kent v. Dulles, 357 U.S. 116, 126 (1958).

137. See Griswold v. Connecticut, 381 U.S. 479 (1965) (recognizing a right to use contraceptives); Stanley v. Georgia, 394 U.S. 557 (1969) (recognizing a right to possess obscene materials within the home).

138. Roe v. Wade, 410 U.S. 113 (1973); see also Bowers v. Hardwick, 478 U.S. 186 (1986) (holding that there is no right to engage in homosexual sodomy within the home if it is prohibited by the state).

139. 302 U.S. 319 (1937) (holding that the prohibition against double jeopardy was not a fundamental right).

140. Id. at 325 .

141. Id. at 326 (quoting Twining v. New Jersey, 211 U.S. 78, 99 (1908)). A fundamental right warrants the strictest standard of review. $I d$.

142. Griswold, 381 U.S. at 487. 
With regard to smoking bans, "[a]lthough tobacco enjoys a long tradition in American history, the 'conscience of the people' supports protecting children from the hazards of second-hand smoke." 143 Regardless, the courts have already determined that smoking is not a fundamental right. ${ }^{144}$ Because there is no fundamental right to smoke, a smoking ban on vehicles carrying minors must only bear a rational relation to a legitimate Government objective in order to be valid. Prohibiting smoking in vehicles occupied by children furthers the Government's interest in protecting the child from the dangers of SHS. Thus, smoking bans on vehicles are rationally related to the Government's legitimate objective and do not impermissibly violate privacy rights.

\section{Parens patriae: the interests of the child trump the rights of the smoker}

Although people have the right to engage in adult and legal decisions (i.e. smoking), that right "does not include the right to inflict health-destructive secondhand smoke upon other persons, especially children who have no choice in the matter."145 Because there are no fundamental rights involved with the present issue, smoking bans on vehicles create tension between two sets of interests: the smoker and the child. This begs the question: in balancing the smoker's interests with that of the child, which interest ultimately prevails? Furthermore, can and should the state regulate this arena?

As previously mentioned, courts have reached into the private sphere and repeatedly considered parental smoking when making decisions related to custody and visitation proceedings. ${ }^{146}$ Because children are often considered to be a "voiceless" group, courts have reached into the private sphere in order to protect the best interests of the child. The doctrine of parens patriae is the "fundamental rule of law that underlies our system of family courts and juvenile justice, providing that the state is 'the ultimate parent' of children within the care of the juvenile court." "147 The State, acting as parent, has an "urgent interest" $" 148$ in the welfare of the child, and must act to protect the child. ${ }^{149}$ " "It is the interest of youth itself, and of the whole community, that children be ... safeguarded from abuses ....",150 Courts have held that "when the interests of the parent and the child conflict to the point where the child is threatened with

143. Michele L. Tyler, Blowing Smoke: Do Smokers Have a Right? Limiting the Privacy Rights of Cigarette Smokers, 86 GEO. L.J. 783, 796 (1998).

144. In re Julie Anne, 780 N.E.2d at 655; see also 66 A.L.R. 5th Validity, Construction, and Application of Restrictions on Use or Possession of Tobacco Products in Correctional Facilities 237 (1999) (annotation citing to cases that have held that smoking is not a fundamental right).

145. In re Julie Anne, 780 N.E.2d at 656.

146. See id. at 635; DeMatteo, 749 N.Y.S.2d 671.

147. In re Julie Anne, 780 N.E.2d at 653 . Parens patriae means "the state as parent." Id.

148. Id. (citing Lassiter v. Dep't of Soc. Serv., 452 U.S. 18, 27 (1981)).

149. Id. (citing Palmore v. Sidoti, 466 U.S. 429, 433 (1984)).

150. Id. at 655 (quoting Prince v. Massachusetts, 321 U.S. 158, 165,170 (1944)). 
harm[,] the state has an obligation to protect the welfare of the child."151

Under the doctrine of parens patriae, the state has a positive obligation and a duty to protect children from the dangers of SHS. ${ }^{152}$ Because children are often involuntarily exposed to SHS, the harm resulting from such exposure is "egregious." 153 Considering that it has been determined that SHS is particularly detrimental to children, the interests of the child trump the non-fundamental privacy interests of the smoker.

As is evident, some people are not entirely comfortable with the Government or the state reaching into the private sphere in this manner. However, smoking bans on vehicles carrying minors make sense-these bans protect children from a very real danger. Kathleen Dachille, director of the Legal Resource Center for Tobacco Regulation, Litigation \& Advocacy at the University of Maryland School of Law, said " $[\mathrm{t}]$ here are times when it's appropriate to regulate what people can do in their home. The state is responsible for that child."154 Further, in response to critics of smoking bans on vehicles, Richard Greene, Mayor of Bangor, Maine, ${ }^{155}$ stated:

I've heard people [critics] say it's the smoke police or the Gestapo. I think it boils down to common sense: smoking is not good for you. Certainly if you have young children who are in the process of developing and growing, it's even worse for them. You wouldn't say, 'Hey, here's a bottle of mercury. Go bob it around. ${ }^{156}$

By passing smoking bans and regulating the "private" vehicle, the state is acting like a "nanny" or assuming a "paternal" role, which is acceptable in this context because the health interests of the child are being protected. Furthermore, this is the role of the state-if the state does not step in to protect children from the dangers of SHS, then who will?

\section{B. How Will the Government Enforce a Smoking Ban on Vehicles?: The Enforceability Argument}

Critics of smoking bans on vehicles carrying minors also argue that such a

151. Id. (emphasis added) (citing Michael S. Wald, State Intervention on Behalf of "Neglected" Children: Standards for Removal of Children From Their Homes, Monitoring the Status of Children in Foster Care, and Termination of Parental Rights, STAN. L. REV. 625, 638 (1976)).

152. Id.

153. In re Julie Anne, 780 N.E.2d. at 652.

154. Emily Bazar, Laws Prohibit Smoking Around Children, USA TodAY, Nov. 28, 2006, available at $\mathrm{http}: / / \mathrm{www}$.usatoday.com/news/health/2006-11-27-smoking-bans_x.htm.

155. As previously mentioned, Bangor, Maine was the first city to ban smoking in vehicles carrying minors. Haskell, supra note 86.

156. Belluck, supra note 56. 
ban would be difficult to enforce. For example, Ben Henby, a lobbyist for the California Organization of Police and Sheriffs, has said, "[w]hile we support the concept [of smoking bans on vehicles] because we're concerned about things that are cancer-producing, it's almost impossible to enforce."157 This argument fails, however, considering that states are already regulating the "private" vehicle and enforcing seatbelt and helmet laws under the "police power" of the United States. ${ }^{158}$

In states where it is a primary offense ${ }^{159}$ not to wear a seatbelt, a law enforcement officer has the authority to pull over a driver that appears to be violating the law (i.e. not wearing a seatbelt). ${ }^{160}$ Similarly, if a state classifies smoking in vehicles with children present as a primary offense, a law enforcement officer would have the same authority to pull over a driver if the officer witnesses the driver violating the smoking ban (i.e. smoking a cigarette with a child in the vehicle).

Moreover, it appears to be easier for a law enforcement officer to enforce a smoking ban on vehicles than it is to enforce seatbelt laws because after a vehicle stop is made for violating a smoking ban, evidence of the violation remains, such as a cigarette butt or cigarette ashes. While it is true that a person who is pulled over can attempt to conceal his violation (i.e. quickly put on a seatbelt if he was not previously wearing one or dispose of cigarette butts and ashes), it is difficult for a person who has been smoking to rid the vehicle of the smell of cigarette smoke. Thus, if a state can enforce seatbelt and helmet laws, the state can just as easily enforce smoking bans on vehicles. Even if a state classifies the violation as a secondary offense, ${ }^{161}$ the ban is still equally enforceable for the reasons previously stated.

157. DeFao, supra note 96.

158. The Tenth Amendment of the United States' Constitution addresses the powers reserved to the States, and as such, "recognizes the states' authority to regulate public health, safety, welfare, and morals through what is called the police power." Ogle, supra note 37, at 357; See U.S. Const. amend. X.

159. A "primary offense" means a police officer can stop but not search a vehicle if a violation is occurring. See LA. Rev. StAT. ANN. § 32:300.3 (2006); H.B. 1046, 1st Spec. Ses. (Ark. 2006).

160. Id.

161. A "secondary offense" means a person would have to be stopped for some other offense in order to be penalized for smoking. See 5AM Morning News, supra note 92. 


\section{Breaking Down the Walls of the "Castle"-the Government is Already Regulating the "Private" Sphere to Protect Against SHS}

1. SHS as a nuisance ${ }^{162}$-the increase in smoke-free apartments, condominiums ("condos"), and other rental properties

Although people object to smoking bans because they blur the line between public and private conduct, the fact remains that the "private" home is already being regulated; therefore, why should the "private" vehicle be immune from regulation? As the issue of SHS and its harmful effects has become more pressing over the past few years, the United States has seen an increase in smoking bans on rental properties. ${ }^{163}$ These types of smoking bans have been enacted to protect tenants (present and future) from SHS that they could potentially be exposed to by living in close proximity with others - a defining characteristic of rental properties. ${ }^{164}$ Nationwide, forty-eight public housing authorities have enacted smoke-free policies. ${ }^{165}$ Because it is becoming common for rental properties to have some form of a smoking restriction, ${ }^{166}$ it is clear that people are acknowledging a right to breathe air free of SHS, especially when the air is inside one's home.

Many landlords, rental associations, and even cities have taken it upon themselves to ban smoking in their rental units, thus, curtailing non-smokers'

162. A "nuisance" is defined as a "condition, activity, or situation (such as loud noise or foul odor) that interferes with the use or enjoyment of property; esp., a non-transitory condition or persistent activity that either injures the physical condition of adjacent land or interferes with its use or with the enjoyment of easements on the land or of public highways." BLACK's LAW DICTIONARY (8th ed. 2004).

163. Jim Buchta, Condominium Owners Tell Smokers: Take it Outside, STAR TRIBUNE, Feb. 13, 2008, available at http://www.startribune.com/local/15617577.html; see also Wendy Koch, Neighbor Tenants Tangle Over Tobacco, USA ToDAY, Oct. 3, 2007, at 3A [hereinafter Koch 1], available at http://www.usatoday.com/news/nation/2007-10-02-nosmoke_N.htm (As of 2007, tens of thousands of apartments and condos had enacted smoke-free policies).

164. See Buchta, supra note 163; Koch 1, supra note 163.

165. Koch 1, supra note 163.

166. In fact, Utah Code expressly authorizes smoking prohibitions in a rental agreement or lease and gives condominium associations the authority to restrict smoking in units, common areas, and facilities. See UTAH CODE ANN. \$ 57-22-5 (1) (h) (1997) and § 57-8-16 (7) (1997). Further, Utah even defines SHS as a nuisance in its Code:

Secondhand smoke is defined as a nuisance when it drifts into any residential unit a person rents, leases, or owns, from another residential or commercial unit more than once in each of two or more consecutive seven-day periods, and which is injurious to health, indecent, offensive to the senses, or an obstruction to the free use of property, so as to interfere with the comfortable enjoyment of life or property. A nuisance may be the subject of an action. This does not apply to residential rental units available for temporary rental or hotel or motel rooms. The cause of action is waived if the rental agreement explicitly says tobacco smoke may drift into the apartment.

UTAH CODE ANN. § 78-38-1 (1997). 
exposure to SHS. In Michigan, more than 600 apartments and condos (covering at least 6,000 units) have decided to ban smoking on their property-this figure increased from zero smoke-free rental properties in $2003 .^{167}$ In Maine, $37 \%$ of landlords have enacted smoking bans on their properties. ${ }^{168}$ In Minnesota, La Rive Condominiums was among the first rental properties in the state to vote to make the building smoke-free. ${ }^{169}$ The smoke-free policy for this particular rental property applies to individual units, common areas, garages, and private balconies. ${ }^{170}$ Although current owners who smoke in their units are "grandfathered in," future buyers have to comply with the regulation. ${ }^{171}$ Furthermore, city councils in Calabasas and Belmont, California have passed ordinances that ban smoking in all apartments and condos located within the city limits. ${ }^{172}$ The Calabasas ordinance, which requires $80 \%$ of apartments and condos to be permanently smoke-free by 2012 , exempts current residents from the smoking ban until they move. ${ }^{173}$ The Belmont ordinance, which declares SHS a "public nuisance," 174 makes residents who smoke subject to fines and evictions if they do not cease smoking upon complaint by their neighbors. ${ }^{175}$ The Belmont ordinance went into effect in January 2009, allowing current residents who smoke to vacate the premises without violating their lease. ${ }^{176}$

The push to make rental properties and residential units smoke-free has been met with its fair share of opposition; ${ }^{177}$ however, a majority of courts have sided with non-smoker residents, ruling SHS a "nuisance."178 A study conducted by the Center for Energy and the Environment in St. Paul, Minnesota, found that as much as half of the air in a residential unit of an apartment building or condo comes from other units. ${ }^{179}$ Thus, it is fair to say that resident smokers not only expose non-smoker neighbors to the smell of smoke, but they also expose non-smoker neighbors to the harmful effects of SHS. Due to the close proximity of the living structure of rental properties and multi-unit hous-

167. Koch 1, supra note 163.

168. Id. (noting that landlords in Maine have received few complaints about their smokefree policies in rental units).

169. Buchta, supra note 163.

170. Id.

171. Id.

172. NBC11, It's Official-Belmont Bans Smoking in Some Homes (Oct. 10, 2007), http://www.nbc11.com/news/14307719/detail.html; Joann Groff, Calabasas Gives Final Okay to Apartment Smoking Ban, THE ACORN, Jan. 24, 2008, http://www.theacom.com/news/2008/ 0124/community/006.html; see also Wendy Koch, Two California Cities to Vote on Banning Smoking in Apartments, USA TODAY, Oct. 3, 2007, at 1A, available at http://www.usatoday. com/printedition/news/20071003/1a_bottomstrip03.art.htm [hereinafter Koch 2].

173. Groff, supra note 172.

174. NBC11, supra note 172.

175. Koch 2, supra note 172.

176. NBC11, supra note 172.

177. Koch 1, supra note 163 . Since 1991, approximately twenty-seven lawsuits have been filed over smoking in apartments and condos. Id.

178. Id.

179. Buchta, supra note 163. 
ing, SHS that drifts into neighboring apartments or condos is at the very least a nuisance. ${ }^{180}$ Because SHS also poses a health risk, it is likely that more rental properties will take the necessary steps to eliminate SHS exposure. Jim Bergman, director of the Smoke-Free Environments Law Project, said "smoke-free housing is a win-win for the rental industry, because landlords can reduce fire risks and cleaning costs while pleasing the approximately $80 \%$ of American adults who don't smoke."181 Therefore, if the "private" home is already being regulated to protect non-smoker residents from the nuisance of SHS, then it seems reasonable to regulate the "private" vehicle to protect children.

2. Not protecting against SHS may be a violation of the covenant of quiet enjoyment ${ }^{182}$ and/or the implied warranty of habitability ${ }^{183}$-landlord/tenant cases

Some courts have gone a step further and considered SHS as more than a nuisance, ruling that landlords could be violating their statutory obligations to tenants if non-smoker residents are exposed to SHS. For example, in the case of Dworkin v. Paley, ${ }^{184}$ a non-smoker tenant sought to terminate his lease and recover his security deposit after SHS exposure from a unit below him caused him physical discomfort on a continuous basis. ${ }^{185}$ In his complaint, the tenant alleged that by allowing him to be exposed to SHS after repeated protests, his landlord violated the covenant of quiet enjoyment and other duties owed to him. ${ }^{186}$ Although the landlord filed a motion for summary judgment ${ }^{187}$ and claimed that she never guaranteed that the building would be smoke-free, the Ohio court held that a genuine issue of material fact existed because "reasonable minds could come to different conclusions concerning whether the condition of ... the rental unit, i.e., the smoke, was sufficient to constitute a breach of the covenant of quiet enjoyment or a breach of any of the landlord's duties.. .."188 Thus, the Ohio court left open the possibility that a landlord, who does not guarantee a smoke-free building, could be in violation of his or her landlord

180. Koch 1, supra note 163; Buchta, supra note 163.

181. Id.

182. The covenant of quiet enjoyment is breached when the landlord "obstruct[s], interfere[s] with, or take[s] away from the ... [tenant] in a substantial degree the beneficial use ... of the leasehold." Dworkin v. Paley, 93 Ohio App. 3d 383, 386 (Ohio Ct. App. 1994).

183. The implied warranty of habitability "provide[s] modern urban dwellers with much needed protections and rights to compel landlords to make necessary repairs and essential services." Poyck v. Bryant, 820 N.Y.S.2d 774, 776 (N.Y. Civ. Ct. 2006). Within the implied warranty of habitability is the expectation that "tenants are not subjected to any conditions endangering or detrimental to their life, health or safety." Id. at 701 .

184. 93 Ohio App. 3d. 383.

185. Id. at 385 .

186. Id.

187. Summary judgment is granted if "there is no genuine issue as to any material fact and the moving party is entitled to judgment as a matter of law." Id. at 386.

188. Id. at 388 . 
duties if non-smoker tenants are exposed to SHS from other tenants.

Similarly, in the case of Poyck v. Bryant, the New York civil court was asked to decide if SHS from a smoker tenant "gives rise to a breach of the implied warranty of habitability and a constructive eviction ${ }^{189}$ under the realities of modern urban dwelling."190 In this particular case, a landlord brought an action to collect rent and late fees from two tenants. ${ }^{191}$ The tenants, however, denied the allegations in the complaint and countered by asserting a breach of the warranty of habitability and constructive eviction because the landlord did not take any actions to prevent the SHS from another tenant that incessantly drifted into the non-smoker tenants' unit. ${ }^{192}$ The court stated that " $[t]$ here is a duty to protect each other's right to privacy and a responsibility not to invade a neighbor's privacy. The unwanted invasion of privacy comes in many guises such as noise, smells, odors, fumes, dust, water and even secondhand smoke." 193 The court held that because SHS is a condition that invokes the protections of the warranty of habitability and other landlord duties, there were triable issues of fact that warranted a denial of summary judgment for the landlord. ${ }^{194}$ Thus, if the landlord fails to protect non-smoker tenants from SHS exposure, it appears that landlords can be held responsible for the actions of their third-party tenants under the implied warranty of habitability

\section{A Minor Restrained in a Smoky Vehicle is Like a Prisoner Confined to a Cell-A Parallel to Smoking Bans in Prisons}

Motivated by the health risks posed by SHS, many jails and prisons across the United States have restricted or banned smoking within their facilities. ${ }^{195}$ Under these smoke-free policies, confined prisoners are not forced to breathe SHS from other prisoners who smoke within the facility. ${ }^{196}$ As of 2002, approximately thirty-eight state correctional departments reported total bans or at least partial bans on smoking in their facilities, ${ }^{197}$ and by 2006 there were only twenty-one states that had not completely banned smoking on prison property. ${ }^{198}$ The Federal Bureau of Prisons has also enacted a near total ban on smoking inside its prisons. ${ }^{199}$

189. Constructive eviction is "[a] landlord's act of making premises unfit for occupancy, often with the result that the tenant is compelled to leave." BLACK's LAW DICTIONARY (8th ed. 2004).

190. Poyck, 820 N.Y.S.2d at 776.

191. Id. at 777.

192. Id.

193. Id. at 776.

194. Id. at 780 .

195. Gregg Zoroya, Smoking Bans Spread to Prisons, USA ToDAY, July 21, 2004, available at http://www.usatoday.com/news/nation/2004-07-21-prison-smoking-usat_x.htm.

196. In re Julie Anne, 780 N.E.2d at 654.

197. Zoroya, supra note 195.

198. Id.

199. See Wilcox, supra note 41, at 2090. 
The Supreme Court has even ruled that a prisoner involuntarily subjected to SHS in his cell may have a claim for cruel and unusual punishment under the Eighth Amendment ${ }^{200}$ because of the health risks associated with SHS. ${ }^{201}$ In the case of Helling $v$. McKinney, a prisoner brought an action alleging a violation of the Eighth Amendment after he was placed in a cell with a heavy smoker and repeatedly exposed to SHS. ${ }^{202}$ The Supreme Court reasoned:

[W]hen the State takes a person into its custody and holds him there against his will, the Constitution imposes upon it a corresponding duty to assume some responsibility for his safety and general well being . . . The rationale for this principle is simple enough: when the State by the affirmative exercise of its power so restrains an individual's liberty that it renders him unable to care for himself, and at the same time fails to provide for his basic human needs-e.g., food, clothing, shelter, medical care, and reasonable safety-it transgresses the substantive limits on state action set by the Eighth Amendment .... ${ }^{203}$

The Court further found that basic decency also demands that prisoners should not be subjected to unreasonable health risks caused by SHS. ${ }^{204}$ The Court stated that, "deliberate indifference to serious medical needs of prisoners violates the [Eighth] Amendment because it constitutes the unnecessary and wanton infliction of pain contrary to contemporary standards of decency.",205 By not protecting children from the harmful effects of SHS, a state's inaction is equivalent to the "deliberate indifference" that the Court in Helling found would constitute cruel and unusual punishment.

Prisoners and children in vehicles are in a similar, unique situation because both are exposed to SHS in confined spaces with high concentrations of SHS. A prisoner, in his or her living quarters, is confined to a cell that is typi-

200. Under the Eighth Amendment, prisoners are not to be subjected to cruel and unusual punishment. Id. at 2087.

201. Helling v. McKinney, 509 U.S. 25, 35 (1993); see also In re Julie Anne, 780 N.E.2d at 654 (citing Seena K. Foster, Annotation, Validity, Construction, and Application of Restrictions on Use or Possession of Tobacco Products in Correctional Facilities 66 A.L.R. FED. 5th 237 (1999) (Prisoners cannot be involuntary exposed to SHS because it is detrimental to their health)).

202. Helling, 509 U.S. at 25.

203. Id. at 32 (quoting Deshaney v. Winnebago County Dep't of Social Servs., 489 U.S. $189,199-200(1989))$.

204. Id.

205. Id. (quoting Estelle v. Gamble, 429 U.S. 97, 103-104 (1976); see also Wilcox, supra note 41, at 2088 (Although prisoners do not have a right to live in "comfortable prisons," the Eighth Amendment guarantees "a minimal civilized measure of life's necessities") (quoting Rhodes v. Chapman, 452 U.S. 337, 349 (1981)). 
cally eight foot by eight foot in size. ${ }^{206}$ While most people would agree that a jail or prison cell has very limited space, children, on the other hand, are restrained to an even smaller amount of space when they are inside a vehicle because of the lack of actual and open space. Thus, like a prison cell, a vehicle magnifies the potential risks from SHS. Because prisoners and children in smoke-filled vehicles are restricted to such confined spaces, they are unable to seek refuge from SHS exposure. ${ }^{207}$

Additionally, the fact that prisoners and children are involuntarily exposed to SHS in cells and vehicles offends notions of decency. If a nonsmoker goes to a bar or restaurant that does not maintain a smoke-free environment, they can choose whether or not to remain in that environment and be exposed to SHS. Unfortunately, prisoners and children do not have that luxury - their freedom to choose to leave a smoke-filled environment is limited or non-existent. Prisoners who are exposed to SHS cannot simply walk out of their cell to avoid potential harm - they instead, gave up those rights on the day they were convicted and sentenced to jail or prison. Similarly, children have very little choice in whether or not they are exposed to SHS in vehicles. Younger children are either unable to vocalize their complaints or are unaware of the harmful effects of SHS. Older children may not be aware of the effects of SHS and also may worry that if they speak up and object to smoking in the vehicle, they will "get in trouble" or upset the person who is smoking.

Prisoners have been deemed worthy of the most basic standards of decency, so why then, are children, who are one of the most, if not the most, defenseless class of individuals, being overlooked? Moreover, if a majority of prisoners are not forced to breathe SHS in a confined space and are protected from the dangers of SHS, then why are children not afforded that same protection? Furthermore, when children are restrained in smoky vehicles, they are themselves prisoners/captives in the vehicle, but the only thing children are guilty of is being of a vulnerable age that has no, or very limited, choice about whether to be exposed to SHS. Thus, if prisoners are shielded from SHS, then children definitely should not be forced to breathe SHS in a confined space like the vehicle.

206. WikiAnswers.com, What is the average size of a US prison cell?, $\mathrm{http}: / /$ wiki.answers.com/Q/What_is_the_average_size_of_a_US_prison_cell (last visited Sept. 30,2008 ).

207. See Wilcox, supra note 41, at 2085 (Prisoners cannot escape breathing air that has been contaminated with SHS) (citing Lisa Gizzi, Helling v. McKinney and Smoking in the Cell Block: Cruel and Unusual Punishment?, 43 AM. U.L. REv. 1091, 1129 (1994)). 


\section{IT IS TIME FOR INDIANA TO TAKE ACTION: INDIANA NEEDS TO PASS A SMOKING BAN ON VEHICLES CARRYING MINORS}

\section{A. Smoking \& Indiana: The Startling Statistics}

Tobacco plays a big role in the state of Indiana. Considering that the state ranks ninth in tobacco production, ${ }^{208}$ it is not surprising that Indiana has the second highest rate of smoking amongst adults. ${ }^{209}$ Not only do almost $27 \%$ of adults in Indiana smoke cigarettes, but approximately 9,700 adults in Indiana die each year from smoking. ${ }^{210}$ Logically, this places a large financial burden on the state. Each year, medical costs in Indiana attributable to smoking reach almost $\$ 2$ billion. ${ }^{211}$ In addition, "[f]or every pack of cigarettes sold in Indiana, Hoosiers spend $\$ 7.10$ in health care costs related to smoking. $" 212$

Consequently, with the alarming number of smokers in Indiana, SHS has a big impact on the state. It is estimated that every year between 1,020 and 1,820 nonsmokers, including children, die from SHS in Indiana. ${ }^{213}$ Furthermore, approximately 420,000 children are exposed to SHS in their Indiana homes. ${ }^{214}$ The appropriate inference is that the same amount of children, if not more, are exposed to SHS in vehicles. Clearly, SHS is a very real problem for Indiana. Children in Indiana are being adversely affected by SHS and remain an "exposed" population because the state has not yet enacted any bans that protect children from SHS, other than in the child or foster care setting. ${ }^{215} \mathrm{Be}$ cause of the pervasiveness of SHS, it is time for Indiana to step up to the plate and enact a smoking ban on vehicles carrying minors.

\section{B. Common Sense Legislation: A Proposed Plan for Indiana}

\section{A step in the right direction: the ban that almost was}

Because Indiana is a key player in tobacco production, ${ }^{216}$ one would think that the chances are slim that Indiana will ever pass a smoking ban on vehicles.

208. UNITED STATES DEPARTMENT OF AgRICULTURE, NATIONAL AGRICULTURE STATISTICS SERVICE, INDIANA FIELD OFFICE (2004), http://www.in.gov/dwd/files/ Indiana_Crop_Production pg2. pdf (last visited Sept. 30, 2008).

209. Indiana Tobacco Prevention and Cessation, Indiana's Tobacco Burden (July 10, 2006), http://www.in.gov/itpc/files/research_87.pdf (last visited Sept. 30, 2008).

210. Id.

211. Id.

212. Id.

213. Campaign for Tobacco-Free Kids, The Toll of Tobacco in Indiana (2005), http://tobaccofreekids.org/reports/settlements/tol.php?stateID=IN.

214. Id.

215. See IND. CoDE $\S 16-41-37-1$ et seq. (2003).

216. See supra note 208 and accompanying text. 
However, State Representative Charlie Brown (D-IN) ${ }^{217}$ transformed a slim possibility into a real possibility when he authored and introduced legislation in 2007 that addressed smoking in vehicles carrying children. ${ }^{218}$ At the suggestion of some constituents in his district, ${ }^{219}$ Representative Brown introduced House Bill 1337, which proposed to ban smoking in vehicles when children under the age of thirteen ${ }^{220}$ are present. ${ }^{221}$ Violators of the proposed ban would be subject to a $\$ 25$ fine for the first offense and $\$ 100$ fine for subsequent violations. ${ }^{222}$ The ban made smoking in vehicles with children present a secondary offense. $^{223}$ According to Representative Brown, he was urged to author this type of legislation because his constituents are tired of seeing adults smoke in their vehicles while children are present. ${ }^{224}$ At the time he introduced the proposed ban, Representative Brown was unaware that Arkansas and Louisiana had already passed such legislation. ${ }^{225}$

Although the proposed bill received positive feedback and passed the first and second readings before the Committee on the Judiciary, ${ }^{226}$ it was ultimately defeated at the third reading, ${ }^{227}$ where it did not receive the required number of votes to continue in the process to become new legislation. ${ }^{228}$ Further, an al-

217. Representative Brown, who lives in Gary, Indiana, was elected to the Indiana House of Representatives for the third district in 1982. Indiana General Assembly, Indiana State Representative Charlie Brown (2008), http://www.in.gov/legislative/house democrats/brown biography.html. Representative Brown, chairman of the Indiana House Standing Committee on Public Health, played a key role in 2007 in "enacting a new statewide effort to promote improved health care for Hoosiers." Id. Further, Representative Brown helped establish a proactive statewide smoking cessation/prevention program in Indiana. Id.

218. H.B. 1337, 114th Gen. Assem., Reg. Sess. (Ind. 2007).

219. Telephone Interview with Representative Charlie Brown, Indiana State Representative, in Indianapolis, Ind. (Feb. 7, 2008).

220. Id. (according to Representative Brown, he decided to draw the line at age thirteen because of the issue of "choice." He stated that it is more likely that the younger children are unable to be left at home by themselves or with a babysitter, and instead will have to travel with the adult in the vehicle. Representative Brown further stated that younger children have no other choice in the matter, but children aged thirteen and older have more of a choice as to whether they ride in a vehicle with a smoker or stay home.)

221. H.B. 1337, 114th Gen. Assem., Reg. Sess. (Ind. 2007).

222. Id.

223. Id.

224. Telephone Interview with Representative Charlie Brown, supra note 219.

225. Id.

226. Id.

227. 3rd Reading on $H B$ 337, Smoking in a vehicle with children, Before the $H ., 115$ th Gen. Assem., Reg. Sess. (Feb. 21, 2007) (defeated 51 to 43), available at http://www.in.gov/ legislative/bills/2007/PDF/Hrollcal/0188.PDF.pdf.

228. Telephone Interview with Representative Charlie Brown, supra note 219; see also Indiana General Assembly, State House Tour Office-How a Bill Becomes a Law (2001), http://www.in.gov/idoa/files/BillintoLaw.pdf. In order for a Bill to become a law in Indiana, it must complete these (over-simplified) steps: 1) a Bill is drafted and introduced;2) a Bill has its first reading where it originated; 3) a Bill is assigned to a committee and the committee takes action on it; 4) a Bill is sent back for a second reading; 5) the House of origin holds a third reading and the Bill is voted on; 6) the process repeats in the other chamber; 7) the Bill returns to the house of origin; 8) the Bill is assigned to a conference committee; 9) the Bill is sent to the Governor; 10) the Bill (assuming it has survived all of the other steps) becomes law. Id. 
most identical bill was introduced on January 8,2008 , but it was withdrawn on January 14, 2008. ${ }^{229}$ As Chairman of the Public Health Committee and a person who is admittedly very interested in the issue of SHS, Representative Brown was "shocked and disappointed" when his proposed bill did not pass. ${ }^{230}$ Representative Brown recognizes the harmful effects that SHS has on children and emphasizes the fact that children are defenseless when it comes to SHS exposure and have no means to avoid it. ${ }^{231}$ Further, Representative Brown thinks that adults should be more responsible in this arena because children's health costs associated with SHS exposure are ultimately coming out of tax dollars. ${ }^{232}$ Although some of his colleagues argue that this type of legislation is too intrusive into private lives, Representative Brown points out that the Government already sets policy for almost every facet of life and that this area should be no different, especially when it is an issue concerning the welfare of children. ${ }^{233}$ Further, Representative Brown stated, "[i]f we can justify [telling parents] that their kids have to go to school until age sixteen, we can require that parents not smoke in vehicles.",234

Representative Brown has brought the state one step closer to passing a ban on smoking in vehicles carrying children. Not only has Representative Brown spread the word and gained support in favor of these types of bans, but he has also provided the state of Indiana hope that it can one day pass a smoking ban on vehicles. Although Representative Brown acknowledges the major role tobacco plays in the State, he indicated that he thinks it is very likely that Indiana will pass this type of ban in the future. ${ }^{235}$ Further, Representative Brown intends to introduce his Bill again in upcoming legislative sessions. ${ }^{236}$

\section{Where does Indiana go from here?}

Although Representative Brown has taken the initiative to introduce legislation that would eliminate children's exposure to SHS in vehicles, ${ }^{237}$ Indiana has not enacted such a ban and as a result, the children of Indiana remain exposed to the dangers of SHS. Clearly, there is substantial evidence surrounding SHS and its effects on children. ${ }^{238}$ Indiana must act now to protect children from the risks posed by SHS exposure. With so many adult smokers in Indiana,

229. H.B. 1056, 115th Gen. Assem., Reg. Sess. (Ind. 2008). This bill proposed to ban smoking in vehicles carrying children under thirteen years of age. Id. Violators would be subject to a $\$ 25$ fine for a first offense and a $\$ 100$ fine for subsequent violations. IId.

230. Telephone Interview with Representative Charlie Brown, supra note 210.

231. Id.

232. Id.

233. Id.

234. Id.

235. Id.

236. Telephone Interview with Representative Charlie Brown, supra note 210.

237. See supra notes $220-223,225$ and accompanying text.

238. See supra Part I.D.1. and accompanying text. 
Hoosiers should be especially concerned about SHS and its potential impact on the state and the state's children. The only way to ensure that children can breathe fresh air free from SHS is to regulate the areas in which children are still being exposed. Thus, Indiana needs to pass a smoking ban on vehicles carrying minors.

As seen through the practice of other states, it is possible and very reasonable to enact a smoking ban on vehicles carrying minors. ${ }^{239}$ Although bans in Arkansas, California, and Louisiana vary in their age restrictions, application, and penalties resulting from the bans, the primary focus remains the same: the children. ${ }^{240}$ Arguably, as long as a state enforces a smoking ban that protects some age group within the class "children," this is better than the alternative of no regulation. However, Indiana needs to go beyond protecting a limited group of children (i.e. six year olds and younger) and instead have a smoking ban on vehicles that protects all minors. Thus, Indiana should prohibit smoking in vehicles when children aged seventeen and younger are present. While it is true that the older a child gets, the more choice and free-will they develop, what "choice" they have may still be limited in some shape or form. Further, people are not allowed to purchase cigarettes until the age of eighteen ${ }^{241}$-an age where people are considered to be adults. If the state has determined that children are not old enough to purchase cigarettes until the age of eighteen, then it is reasonable for Indiana to decide that that same class should be protected from SHS in vehicles.

Unlike California's smoking ban on vehicles carrying minors that classifies violations as secondary offenses, ${ }^{242}$ Indiana's ban should classify violations of the ban as primary offenses. Because SHS and its effects on children are a serious matter, the state needs to treat violations of the law as a serious matter. Further, Indiana needs to make it apparent that it does not condone involuntary exposure to SHS, which would be accomplished by giving the police the authority to make a traffic stop for no other reason than witnessing an adult smoking in a vehicle with a minor present. Moreover, it can be just as easily enforced as pulling someone over for not wearing a seatbelt. ${ }^{243}$

Additionally, those who violate Indiana's smoking ban should be subject to more than just a slap on the wrist. A \$25 fine for a first time offense is not going to get the point across to a violator that he or she should take the law seriously. At a minimum, violators of Indiana's ban should be faced with a fine of $\$ 100$, and subsequent violations should result in increased fines. Further, Indiana should also consider sentencing violators of the smoking ban to community service in addition to or in lieu of a fine.

Unquestionably, children need to be protected from SHS, especially when

239. See supra Part II.A-B and accompanying text.

240. Id.

241. See IND. CoDE § 35-46-1-10.5 (1997).

242. See supra note 94 and accompanying text.

243. See supra Part III.B and accompanying text. 
it comes to a confined space such as the vehicle. Indiana has within its grasp a means to make it happen-a smoking ban on vehicles carrying minors. It is time that Indiana acknowledges the dangers of SHS and the effects of SHS on children by passing legislation that addresses and confronts the issue. With all of the research and data that has conclusively found that SHS poses a serious risk for children, it would be absurd for Indiana not to pass this type of legislation. The children of Indiana are worth it.

\section{CONCLUSION}

There are no ifs, ands, or butts about it-SHS is not safe at any level, in any form, or for any length of time. Further, SHS is particularly harmful to children who are still in the process of growing and developing. Although there has been an increase in smoking bans over the past few years, children are still exposed to SHS in their homes and in vehicles. When children are restrained in smoky vehicles, they breathe in toxins and carcinogens that are typically found in SHS, but at a more concentrated level. The only way to address this issue and to protect children from the damaging effects of SHS is to regulate the private vehicle and prohibit smoking in the vehicle when children are present.

Although opponents argue that these smoking bans violate their privacy rights, there is no fundamental right to smoke. In balancing the health and interests of children with the interests of smokers, the children's rights overwhelmingly outweigh the rights of smokers. Common sense dictates that children - voiceless, defenseless, innocent children - warrant protection. States need to step in and protect children from something that has been proven to be extremely harmful. In addition to common sense, states have a duty to protect children. Adults can choose whether or not to smoke. Nonsmoker adults can choose whether or not to be around SHS. Children, on the other hand, cannot choose and should not be penalized nor have their health jeopardized simply because they are too young to defend themselves or know better than to ride in the same vehicle as a smoker. States are not forcing prisoners to breathe SHS in a confined space. Likewise, children should also not be compelled to breathe SHS in the confined space of a vehicle.

Because three states (Arkansas, California, and Louisiana) have successfully passed legislation addressing smoking in vehicles carrying minors, ${ }^{244}$ it is possible for other states to do so as well. Specifically, Indiana, a state known for tobacco production and with a large number of adult smokers, ${ }^{245}$ needs to join the fight against SHS and prohibit smoking in vehicles carrying minors. By protecting children from potential health problems associated with SHS, a ban like this just makes sense. 
